\title{
AN EVALUATION OF CATALYTIC EMISSION CONTROLS AND VERTICAL EXHAUST STACKS TO PREVENT CARBON MONOXIDE POISONINGS FROM HOUSEBOAT GENERATOR EXHAUST
}

\author{
Anthony T. Zimmer, Ph.D., P.E., C.I.H. \\ G. Scott Earnest, Ph.D, P.E., C.S.P. \\ Robert Kurimo
}

REPORT DATE:

September 2005

REPORT NO.:

EPHB 171-36a

MANUSCRIPT PREPARED BY:

Bernice Clark

\author{
U.S. Department of Health and Human Services \\ Public Health Service \\ Centers for Disease Control and Prevention \\ National Institute for Occupational Safety and Health \\ Division of Applied Research and Technology \\ 4676 Columbia Parkway, MS - R5 \\ Cincinnati, Ohio 45226
}


Site Surveyed:

Callville Bay

Marina

Boulder City, Nevada

SIC Code:

N/A

Survey Dates:

March

7-9, 2005

Employer Representatives Contacted:

John Stenseth, General Manager Fun Country Marine Industries, Inc.

Employee Representatives Contacted:

None 


\section{DISCLAIMER}

Mention of any company or product does not constitute endorsement by the Centers for Disease Control and Prevention (CDC), National Institute for Occupational Safety and Health (NIOSH). 


\section{EXECUTIVE SUMMARY}

Working under an interagency agreement with the United States Coast Guard, researchers from the National Institute for Occupational Safety and Health (NIOSH) evaluated carbon monoxide (CO) emissions, exposures, and controls from gasoline-powered generators on houseboats. This evaluation is part of a series of studies conducted by NIOSH investigators during the past several years to identify and recommend effective engineering controls to reduce the $\mathrm{CO}$ hazard and eliminate CO poisonings on houseboats and other recreational marine vessels.

The performance of two (14 KW and $20 \mathrm{KW}$ ) Westerbeke, Safe-CO ${ }^{\mathrm{TM}}$

Generators were tested. Using electronic fuel injection and a catalytic air pollution control device, these generators were specifically designed to reduce carbon monoxide emissions to protect the boating occupants. To prevent excessive heat buildup in the catalyst, the device was also water jacketed. This represented an improvement over previously tested engineering control devices by reducing their fire hazard potential (Earnest, Dunn et al. 2003). The houseboat containing the $14 \mathrm{KW}$ generator had been modified so that testing could be accomplished using either a side exhaust or top exhaust configuration. At the request of Fun Country Marine, a 12.5 KW Westerbeke generator was also tested that had been retrofitted with a Zenith Electronic Fuel Injection Kit (EFI).

When comparing the real-time results for the side versus top stack exhaust, slightly higher concentrations were noted on the lower stern deck in the side exhaust configuration. Although the use of the low Safe- $\mathrm{CO}^{\mathrm{TM}}$ generator resulted in low $\mathrm{CO}$ concentrations for either configuration, the use of the vertical exhaust is recommended as a prudent control technology. For example, not changing the catalyst would result in performance degradation over time resulting in higher than expected emissions. The use of a vertical stack would insure that exhaust emissions were located well away from boaters to reduce their potential for exposure.

The performance of the Westerbeke Safe- $\mathrm{CO}^{\mathrm{TM}}$ generators was impressive with stack $\mathrm{CO}$ emission of approximately $200 \mathrm{ppm}$ for the fully warmed generator. Due to diffusion, these emissions were significantly reduced such that highest average real-time CO reading, obtained from the monitors placed throughout the houseboat, was $9.3 \mathrm{ppm}$ (side exhaust configuration). In addition, the performance of the Westerbeke generator retrofitted with a Zenith EFI was excellent with a stack $\mathrm{CO}$ emission below 1,000 ppm for the fully warmed generator. Given the low hours of operation for all of the generators tested, it is important to conduct addition tests at the end of the houseboat season to determine if there are any performance degradations. 


\section{BACKGROUND}

On March 7 through 9, 2005, National Institute for Occupational Safety and Health (NIOSH) researchers evaluated control of carbon monoxide (CO) emissions and exposures at Callville Bay Marina on Lake Mead, Nevada. The evaluation primarily involved the evaluation of Westerbeke Safe-CO ${ }^{\text {тм }}$ generators that were installed on two houseboats. A $14 \mathrm{KW}$ Low Safe-CO ${ }^{\text {тм }}$, equipped with an exhaust system that could either be routed to a side exhaust or a vertical stack exhaust, was tested on a Fun County Marine VIP XT (16 X 59'). The second generator, a 20 KW Safe-CO ${ }^{\text {тм }}$ Generator, was installed onto a Fun Country Marine Millenium (16’ X 70’) houseboat. Additionally, a $12.5 \mathrm{KW}$ Westerbeke generator, retrofitted with a Zenith Electronic Fuel Injection (EFI) Kit and installed onto a Fun Country Marine Deluxe (14' X 59') houseboat was tested. All of the evaluations were conducted while the houseboats were docked at the marina.

Initial investigations of carbon monoxide (CO)-related poisonings and deaths on houseboats at Lake Powell were conducted in September and October 2000 involving representatives from NIOSH, U.S. Coast Guard, U.S. National Park Service, Department of Interior, and Utah Parks and Recreation. These investigations measured hazardous $\mathrm{CO}$ concentrations on houseboats at Lake Powell (McCammon and Radtke 2000). Some of the severely hazardous situations identified during the early studies included:

- The open space under the swim platform could be lethal under certain circumstances (i.e., generator/motor exhaust discharging into this area) on some houseboats.

- Some CO concentrations above and around the swim platform were at or above the immediately dangerous to life and health (IDLH) level [greater than 1,200 parts of CO per million parts of air (ppm)].

- Measurements of personal CO exposure during boat maintenance activities indicated that employees may be exposed to hazardous concentrations of CO.

Epidemiological investigations have discovered that from 1990 to 2000, 111 CO poisoning cases occurred on Lake Powell near the border of Arizona and Utah. Seventy-four of the poisonings occurred on houseboats, and 64 of these poisonings were attributable to generator exhaust alone. Seven of the 74 houseboat- related CO poisonings resulted in death (McCammon, Radtke et al. 2001). Further investigations have identified nearly 400 CO poisonings related to recreational boats across the United States and that number continues to increase.

Engineering control studies began in February 2001 at Lake Powell and Somerset, Kentucky, (Dunn, Hall et al. 2001; Earnest, Dunn et al. 2001). Results of these studies demonstrated that an exhaust stack extending 9 feet above the houseboat's upper deck dramatically reduced the CO concentrations on and near the houseboat and provided a much safer environment. A meeting was convened by the U.S. Coast Guard, Office of Boating Safety, Recreational Boating Product Assurance Division on May 3, 2001, in Lexington, Kentucky. This meeting was attended by houseboat manufacturers, marine product manufacturers, government representatives, and others interested in addressing the CO hazard. Following the meeting, NIOSH researchers were asked 
to evaluate the performance of a new prototype ECD and an interlocking device and to conduct further evaluations of the dry stack. These evaluations were conducted in June 2001 at Callville Bay Marina, NV. The findings of these studies indicated that although the ECD, interlock, and dry stack each performed well, longer term testing of the ECD should be conducted (Dunn, Earnest et al. 2001; Earnest, Dunn et al. 2001). A second evaluation of the prototype ECD in October 2001 showed that performance of the prototype ECD had substantially degraded after thousands of hours of use; however, a new production ECD was developed that performed well. The prototype ECD was constructed from a combination of stainless steel and cast iron while the production ECD was constructed entirely of stainless steel to reduce corrosion with several engineering improvements. A follow-up survey was conducted to evaluate the performance of the improved ECD after 2000+ hours of use. The results showed that the improved ECDs were somewhat effective at reducing CO concentrations; however, their performance had substantially degraded from when they were new (Earnest, Dunn et al. 2003).

The following study was primarily conducted to evaluate the performance of a generator that was designed to produce low $\mathrm{CO}$ emissions. To reduce the carbon monoxide emissions, electronic fuel injection (EFI) was employed to efficiently combust the gasoline. To reduce the remaining carbon monoxide emissions in the exhaust effluent, a catalytic air pollution control device was used. At the request of Fun Country Marine, a normal Westerbeke generator, retrofitted with a Zenith EFI, was also tested.

\section{Symptoms and Exposure Limits}

$\mathrm{CO}$ is a lethal poison that is produced when fuels such as gasoline or propane are burned. It is one of many chemicals found in engine exhaust resulting from incomplete combustion. Because $\mathrm{CO}$ is a colorless, odorless, and tasteless gas, it can overcome the exposed person without warning. The initial symptoms of CO poisoning may include headache, dizziness, drowsiness, or nausea. Symptoms may advance to vomiting, loss of consciousness, and collapse if prolonged or high exposures are encountered. If the exposure level is high, loss of consciousness may occur without other symptoms. Coma or death may occur if high exposures continue (NIOSH 1972; NIOSH 1977; NIOSH 1979). The display of symptoms varies widely from individual to individual, and may occur sooner in susceptible individuals such as young or aged people, people with preexisting lung or heart disease, or those living at high altitudes (Proctor, Hughes et al. 1988; ACGIH 1996; NIOSH 2000).

Exposure to $\mathrm{CO}$ limits the ability of the blood to carry oxygen to the tissues by binding with the hemoglobin to form carboxyhemoglobin (COHb). Blood has an estimated 210-250 times greater affinity for $\mathrm{CO}$ than oxygen, thus the presence of $\mathrm{CO}$ in the blood can interfere with oxygen uptake and delivery to the body (Forbes, Sargent et al. 1945).

Although NIOSH typically focuses on occupational safety and health issues, the Institute is a public health agency, and cannot ignore the overlapping exposure concerns in this type of setting. NIOSH researchers have done a considerable amount of work related to controlling CO exposures in the past (Ehlers, McCammon et al. 1996; Earnest, Mickelsen et al. 1997; Kovein, Earnest et al. 1998). The general boating public may range from infant to aged, be in various 
states of health and susceptibility, and be functioning at a higher rate of metabolism because of increased physical activity.

\section{Exposure Criteria}

Occupational criteria for CO exposures are applicable to U.S. National Park Service (USNPS) and concessionaire employees who have been shown to be at risk of boat-related CO poisoning. The occupational exposure limits noted below should not be used for interpreting general population exposures (such as visitors engaged in boating activities) because occupational standards do not provide the same degree of protection as they do for the healthy worker population. The effects of CO are more pronounced and the time of onset of effects is shorter if the person is physically active, very young, very old, or has preexisting health conditions such as lung or heart disease. Persons at extremes of age and persons with underlying health conditions may have marked symptoms and may suffer serious complications at lower levels of carboxyhemoglobin. Standards relevant to the general population take these factors into consideration, and are listed following the occupational criteria

The NIOSH Recommended Exposure Limit (REL) for occupational exposures to CO gas in air is 35 parts per million (ppm) for full shift time-weighted average (TWA) exposure, and a ceiling limit of 200 ppm, which should never be exceeded (CDC 1988; CFR 1997). The NIOSH REL of $35 \mathrm{ppm}$ is designed to protect workers from health effects associated with COHb levels in excess of 5\% (Kales 1993). NIOSH has established the immediately dangerous to life and health (IDLH) value for CO of 1,200 ppm (NIOSH 2000). The American Conference of Governmental Industrial Hygienists $\left(\mathrm{ACGIH}^{\oplus}\right)$ recommends an 8-hour TWA threshold limit value $\left(\mathrm{TLV}^{\oplus}\right.$ ) for occupational exposure of 25 ppm (ACGIH 1996) and discourages exposures above 125 ppm for more than 30 minutes during a workday. The Occupational Safety and Health Administration (OSHA) permissible exposure limit (PEL) for CO is 50 ppm for an 8-hour TWA exposure (CFR 1997).

\section{Health Criteria Relevant to the General Public}

The U.S. Environmental Protection Agency (EPA) has promulgated a National Ambient Air Quality Standard (NAAQS) for CO. This standard requires that ambient air contain no more than 9 ppm CO for an 8-hour TWA, and 35 ppm for a 1-hour average (EPA 1991). The NAAQS for $\mathrm{CO}$ was established to protect the most sensitive members of the general population

The World Health Organization (WHO) has recommended guideline values and periods of timeweighted average exposures related to CO exposure in the general population [WHO 1999]. WHO guidelines are intended to ensure that $\mathrm{COHb}$ levels not exceed $2.5 \%$ when a normal subject engages in light or moderate exercise. Those guidelines are:

$100 \mathrm{mg} / \mathrm{m}^{3}$ (87 ppm) for 15 minutes

$60 \mathrm{mg} / \mathrm{m}^{3}$ (52 ppm) for 30 minutes

$30 \mathrm{mg} / \mathrm{m}^{3}$ (26 ppm) for 1 hour

$10 \mathrm{mg} / \mathrm{m}^{3}$ (9 ppm) for 8 hours 


\section{METHODS}

Carbon monoxide measurements and weather measurements were collected on three houseboats built by Fun Country Marine Industries, Inc. (Muncie, IN). The evaluation primarily involved the evaluation of Westerbeke Safe-CO ${ }^{\mathrm{TM}}$ generators that were installed on two houseboats. A $14 \mathrm{KW}$ Safe-CO ${ }^{\text {тм }}$ Generator, equipped with an exhaust system that could either be routed to a side exhaust or a vertical stack exhaust, was tested on a Fun County Marine VIP XT (16 X 59'). The second generator, a $20 \mathrm{KW}$ Safe-CO ${ }^{\mathrm{TM}}$ Generator, was installed onto a Fun Country Marine Millenium (16' X 70') houseboat. Additionally, a 12.5KW Westerbeke generator, retrofitted with a Zenith Electronic Fuel Injection (EFI) Kit and installed onto a Fun Country Marine Deluxe (14' X 59') houseboat was tested. All of the evaluations were conducted while the houseboats were docked at the marina. Data was collected in an effort to evaluate the performance of the control systems.

The generators on the houseboats provided electrical power for air conditioning, kitchen appliances, entertainment systems, navigation, and communications equipment. The generators were housed in the engine compartment beneath the stern deck near the drive engines. The generators are similar in size to engines used on small automobiles. Westerbeke generators are used on nearly $75 \%$ of houseboats in the U.S. (Westerbeke 2001). When used on houseboats, the hot exhaust gases from the generators are injected with water near the end of the exhaust manifold in a process commonly called water-jacketing. Water-jacketing is used for exhaust cooling and noise reduction. Because the generator is situated below the waterline, the waterjacketed exhaust passes through a lift muffler that further reduces noise and forces the exhaust gases and water up and out through a hole beneath the swim platform.

\section{Description of the Evaluated Engineering Controls}

Each houseboat tested had a continuous, vertical exhaust stack fitted to the generator set. For the purposes of comparing the exhaust location on the results, a Fun Country Marine VIP XT (16' X 59') houseboat was configured to allow the exhaust emissions to be easily changed from a side to top stack exhaust configuration. The exhaust stacks were designed to comply with the revised American Boat and Yacht Council (ABYC) Standard P-1 for recreational boat exhaust. A 2-inch nominal, schedule 40 aluminum pipe, having an approximately 2.5-inch outside diameter and 2.0-inch inside diameter was used as the stack.

The focus of this study was to evaluate the performance of Westerbeke Safe-CO ${ }^{\text {тM }}$ Generators that had been specifically designed to produce low CO emissions. A $14 \mathrm{KW}$ Safe-CO ${ }^{\text {тм }}$ Westerbeke generator was tested on a Fun County Marine VIP XT (16’ X 59') houseboat. 108 hours of generator use had been logged before the evaluation. Additionally, a $20 \mathrm{KW}$ Safe-CO ${ }^{\mathrm{Tm}}$ Westerbeke generator was tested on a Fun Country Marine Millenium (16' X 70') houseboat. 159 hours of use had been logged on this generator before the evaluation. Given the proprietary nature of this technology, little information could be obtained regarding the specific control technologies used to reduce the carbon monoxide emissions. However, an electronic fuel injection system was employed to efficiently combust the gasoline fuel to reduce exhaust emissions, including carbon monoxide. 
Secondly, a catalytic air pollution control device was designed to optimize the chemical oxidation of carbon monoxide in the exhaust generator exhaust emissions (Figure 1). To prevent excessive heat buildup in the catalyst, the device was jacket water cooled. This represents an advantage over the previously tested ECD in reducing its potential for a fire hazard (Earnest, Dunn et al. 2003). According to the manufacturer, the catalyst should be replaced after 2000 hours of use. The manufacturer also recommends that carbon monoxide emissions be spot checked at 1000 hours of use. Stainless steel was selected as the catalyst housing to inhibit corrosion from the harsh marine environment. The catalytic ingredients used in the catalyst were not revealed by the manufacturer, but normally are composed of metal or metal oxides (e.g., Pt, $\mathrm{Pd}, \mathrm{Rh}, \mathrm{V}_{2} \mathrm{O}_{5}$ ). These metals are normally dispersed onto a high surface area porous structure (e.g., $\mathrm{Al}_{2} \mathrm{O}_{3}, \mathrm{SiO}_{2}$ ) located within the catalyst. Exhaust gases adsorbed onto the surface undergo catalytic reactions. A catalyst increases the rate of a chemical reaction without undergoing a permanent change itself (Heck, R.M., Farrauto, R.J., 1995).

At the request of Fun Country Marine, an older model $12.5 \mathrm{KW}$ Westerbeke generator was also evaluated that had been retrofitted with an aftermarket electronic fuel injection kit. The aftermarket kit, a Zenith Electronic Fuel Injection Kit, contained a throttle body injection unit, an engine management module, and a fuel pump/vapor separator. The retrofit involved the removal of the manufacturer's carburetor, mechanical governor, and fuel pump. The generator was placed in a Fun County Marine Deluxe (14' X 59') houseboat. Since the retrofit, 202 hours had been logged onto this generator.

\section{Description of the Evaluation Equipment}

Emissions from the generator and drive engines were characterized using a Ferret Instruments (Cheboygan, MI) Gaslink LT Five Gas Emissions Analyzer. This analyzer measures CO, carbon dioxide $\left(\mathrm{CO}_{2}\right)$, hydrocarbons, oxygen, and nitrogen oxides $\left(\mathrm{NO}_{\mathrm{x}}\right)$. All measurements are expressed as percentages except hydrocarbons and $\mathrm{NO}_{\mathrm{x}}$ which is ppm. [One percent of contaminant is equivalent to $10,000 \mathrm{ppm}$.]

CO concentrations were measured at various locations on the houseboat using ToxiUltra Atmospheric Monitors (Biometrics, Inc.) with CO sensors (Figure 2). ToxiUltra CO monitors were calibrated before and after use according to the manufacturer's recommendations. These monitors are direct-reading instruments with data logging capabilities. The instruments were operated in the passive diffusion mode, with a 15 - 30 second sampling interval. The instruments have a nominal range from $0 \mathrm{ppm}$ to $999 \mathrm{ppm}$. Accuracy is +/- $1 \mathrm{ppm}$ or 5 percent of the reading (whichever is greatest).

CO concentrations were also measured with detector tubes [Draeger A.G. (Lubeck, Germany) $\mathrm{CO}, \mathrm{CH} 29901$ - ranges 2-60 ppm, $10-3000 \mathrm{ppm}$, and 3000-70,000 ppm] in the areas adjacent the side exhaust (i.e., 24" above the exhaust) when testing a houseboat in this configuration mode and directly in the generator exhaust when testing a houseboat in a top exhaust configuration. The detector tubes are used by drawing air through the tube with a bellows-type pump. The 
resulting length of the stain in the tube (produced by a chemical reaction with the sorbent) is proportional to the concentration of the air contaminant.

Grab samples were collected using Mine Safety and Health Administration (MSHA) 50-mL glass evacuated containers. These samples were collected by snapping open the top of the glass container and allowing the air to enter. The containers were sealed with wax-impregnated MSHA caps. The samples were then sent to the Datachem Laboratories, Inc. in Salt Lake City, Utah where they were analyzed for CO using a Varian 3800 gas chromatograph equipped with a methanizer and thermal conductivity, flame ionization and electron capture detectors.

Wind velocity measurements were gathered each minute during the air sampling using an omnidirectional (Gill Instruments Ltd., Hampshire, U.K.) ultrasonic anemometer. This instrument uses a basic time-of-flight operating principle that depends upon the dimensions and geometry of an array of transducers. Transducer pairs alternately transmit and receive pulses of high frequency ultrasound. The time-of-flight of the ultrasonic waves are measured and recorded, and this time is used to calculate wind velocities in the $\mathrm{X}$ - and Y-axes. This instrument is capable of measuring wind velocities of up to 45 meters per second (m/sec) and take 100 measurements per second. Temperature and relative humidity measurements were collected using a TSI Velocicalc Plus (Model 8360, St. Paul, MN).

\section{Description of Procedures}

The evaluation was performed over a 3-day period using a variety of operating conditions and generator exhaust configurations. In each case, the houseboats were tested while moored at the marina. Details concerning the testing of each houseboat are summarized below:

- Fun Country Marine VIP XT (16' X 59') with a 14 KW Safe-CO ${ }^{\text {тм }}$ Westerbeke Generator. In this houseboat, the generator emissions could be configured to exhaust either through a side or vertical exhaust stack. Additionally, testing was accomplished under no-load and $1 / 2$ load conditions. $1 / 2$ load conditions were accomplished by running the air conditioning unit. In each case, $1 / 2$ load conditions were placed on the generator when it had been warmed (30+ minutes of operation under no-load generator operation).

- Fun Country Marine Millenium (16' X 70') with a 20 KW Safe-CO ${ }^{\text {тм }}$ Westerbeke Generator. In this houseboat, the generator emissions were configured to only exhaust from a vertical exhaust stack. Additionally, testing was accomplished under no-load and $1 / 2$ load conditions. $1 / 2$ load conditions were accomplished by running the air conditioning unit. In each case, $1 / 2$ load conditions were placed on the generator when the generator had been warmed (30+ minutes of operation under no-load generator operation).

- Fun Country Marine Deluxe (14’ X 59') with a 12.5 KW Westerbeke Generator retrofitted with a Zenith Electronic Fuel Injection Kit. In this houseboat, the generator emissions were configured to only exhaust from a vertical exhaust stack. Additionally, testing was accomplished under no-load and $1 / 2$ load conditions. 1/2 load conditions were accomplished by running the air conditioning unit. In each case, $1 / 2$ load 
conditions were placed on the generator when the generator had been warmed (30+ minutes of operation under no-load generator operation).

Sampling locations for the ToxiUltra real-time CO monitors on the lower and upper decks of the houseboats, designated with numbers, are shown in Figure 2. The monitors were placed at nine sample locations on the upper and lower decks of the houseboat to provide representative samples of occupied areas. Grab samples using the Ferret Instrument Gas Analyzer, Draeger detector tubes, and evacuated containers were also taken near (i.e., side exhaust configuration) or within the generator exhausts (top exhaust configuration). Additionally, wind direction and speed measurements were monitored during the testing using an ultrasonic anemometer while temperature and relative humidity measurements were monitored using a TSI Velocicalc Plus.

\section{RESULTS}

\section{Results of Air Sampling with ToxiUltra CO Monitors}

Real-time CO monitoring was conducted at several locations on the houseboat (Figure 2). The summary statistics for this data are provided in Tables I through IV. Details concerning the sample results for each houseboat are summarized below:

\section{- Fun Country Marine VIP XT (16’ X 59') with a 14 KW Safe-CO ${ }^{\text {тм }}$ Westerbeke} Generator. As evident by Table I-II, the CO emissions on both the lower and upper decks were quite low. When comparing the real-time results for the side versus top stack exhaust, slightly higher concentrations were noted on the lower stern deck. For example, an average and peak value of 9.3 and 60 ppm, respectively, occurred at sample location 2 for the side exhaust configuration. In comparison, an average and peak value of 6.9 and $15 \mathrm{ppm}$, respectively, was noted in the top exhaust configuration at the same location. A generator load increase to one half of capacity did not appear to influence CO emissions, although these measurements were taken when the engine was already warmed.

- Fun Country Marine Millenium (16' X 70') with a 20 KW Safe-CO ${ }^{\text {тм }}$ Westerbeke Generator. The results for this generator were also low as illustrated by Table III. The highest peak concentration found during this test was $10 \mathrm{ppm}$ (sample location 7). A generator load increase to one half of capacity appeared did not appear to affect $\mathrm{CO}$ emissions (engine was warmed).

- Fun Country Marine Deluxe (14’ X 59') with a 12.5 KW Westerbeke Generator retrofitted with a Zenith Electronic Fuel Injection Kit. Measured CO concentrations were comparable to the previous tests using vertical exhaust stacks. The highest peak concentration found during this test was 18 ppm (sample location 2). A generator load increase to one half of capacity did not appear to influence CO emissions, although these measurements were taken when the engine was already warmed. 
Gas Emissions Analyzer, Detector Tubes, and Evacuated Container Results

Gas emissions analyzers, detector tubes, and glass evacuated containers were used to

characterize CO concentrations in and near the exhaust stack. This equipment was utilized because it is capable of reading higher $\mathrm{CO}$ concentrations than the ToxiUltra CO monitors which have an upper limit of approximately 1,000 ppm. The grab sample data is summarized in Table $\mathrm{V}$ and is presented for each houseboat in the following:

Fun Country Marine VIP XT (16' X 59') with a 14 KW Safe-CO ${ }^{\text {тм }}$ Westerbeke Generator. As evident by Table V, CO concentrations for the side exhaust configuration for both the no-load and $1 / 2$ load conditions were primarily none detected. The highest reading, 126 ppm, was taken using the evacuated chamber. These results are reasonable in that the measurement locations were approximately 24” from the emission source. In contrast, measurements taken within the vertical exhaust stack exhaust plume reached 15,600 ppm during the cold start of the generator and decreased to very low values approximately 5 minutes later. When comparing the fully warmed $1 / 2$ load condition to the no load condition, there did not appear to be a significant difference in CO measurements.

- Fun Country Marine Millenium (16’ X 70') with a 20 KW Safe-CO ${ }^{\text {тм }}$ Westerbeke Generator. As evident by Table V, CO concentrations taken within the vertical exhaust plume increased rapidly after the cold start, exceeding eleven percent (116,000 ppm) CO. Within several minutes, the CO measurements appeared to stabilize to an approximately $200 \mathrm{ppm}$. For the fully warmed $1 / 2$ load condition, an initial increase to $1700 \mathrm{ppm}$ was measured using the Ferret Instrument. These values decreased and stabilized after several minutes to a steady state value of approximately $240 \mathrm{ppm}$.

- Fun Country Marine Deluxe (14’ X 59') with a 12.5 KW Westerbeke Generator retrofitted with a Zenith Electronic Fuel Injection Kit. As evident by Table V, CO concentrations taken within the vertical exhaust plume increased rapidly after the cold start, exceeding eleven percent $(117,000 \mathrm{ppm}) \mathrm{CO}$. Within several minutes, the CO measurements appeared to stabilize to below $1,000 \mathrm{ppm}$. For the fully warmed $1 / 2$ load condition, the CO level slightly increased with the initial application of load (19,400 ppm) and decreased within several minutes to steady-state values measured during the no load test.

\section{Weather Measurements}

Wind velocity measurements were gathered during the survey with an ultrasonic anemometer. Much of the testing occurred at the marina where the three houseboats were oriented at a constant bearing of $300^{\circ}$ (roughly northwest). A summary of wind velocity data is shown in Table IV. This table provides data concerning the bearing of the houseboat, temperature, relative humidity, average wind direction, average wind speed, and the standard deviation of the wind speed. As illustrated by this table, the predominant wind direction tended to direct the generator emissions back into the houseboat (worst case condition). Additionally, the wind speeds were light and variable. The highest average wind speed was $1.8 \mathrm{~m} / \mathrm{s}$ (4 miles per hour) measured on 
the morning of March $9^{\text {th }}$. These low wind speeds would also tend to create conditions that would be considered "worst case” for houseboat occupants.

\section{DISCUSSION AND CONCLUSIONS}

The CO hazard to swimmers and occupants on houseboats that have gasoline-powered generators can be greatly reduced by retrofitting engineering control systems to the generators. Previous studies have shown that an exhaust stack (that releases the $\mathrm{CO}$ and other emission components high above the upper deck of the houseboat) allows the contaminants to diffuse and dissipate into the atmosphere away from boat occupants (Dunn, Hall et al. 2001; Earnest, Dunn et al. 2001).

This study is the first to evaluate the performance of a generator that was specifically designed to reduce carbon monoxide emissions and protect boat occupants. Additionally, tests were conducted to determine the performance of the Westerbeke Safe-CO ${ }^{\text {тм }}$ generators based upon the configuration (side exhaust versus top stack exhaust and to allow sampling directly in the exhaust) as well as the electrical load (no load versus $1 / 2$ load). At the request of Fun Country Marine, an older, Westerbeke generator was also tested that had been retrofitted with an aftermarket EFI.

\section{Exhaust Configuration}

Data was gathered from a Fun Country Marine VIP XT (16’ X 59’) houseboat using a 14 KW Low CO Westerbeke Generator that could be configured to exhaust the generator emission from a side exhaust or top stack exhaust configuration. The results of air sampling with ToxiUltra CO Monitors located on the lower and upper decks demonstrated low CO emissions for both configurations (Table I-II). When comparing the real-time results for the side versus top stack exhaust, slightly higher concentrations were noted on the lower stern deck. Although the use of the Safe-CO ${ }^{\mathrm{TM}}$ generator resulted in low $\mathrm{CO}$ concentrations for either configuration, the use of the vertical exhaust is recommended as a redundant safety measure. For example, not changing the catalyst would result in performance degradation over time resulting in higher than expected emissions. The use of a vertical stack would insure that exhaust emissions were located well away from boaters to reduce their potential for exposure.

\section{Westerbeke Low CO Generator Performance}

$\mathrm{CO}$ results for both of the Safe-CO ${ }^{\text {TM }}$ generators tested were quite promising (Tables I-III and $\mathrm{V})$. As expected, the cold start condition resulted in initial transient concentrations greater than 11 percent within the stack. However, as the catalytic control device warmed to an optimal efficiency, the stack emissions dramatically reduced to approximately $200 \mathrm{ppm}$ (1000 fold decrease) after approximately 5 minutes. An increase in electrical load (1/2 load) resulted in a transient increase in emissions followed by a decrease to the steady state concentrations seen in the no load condition. The generators tested had low hours of operation (108 to 159 hours). To prevent excessive heat buildup in the catalyst, the device was also jacket water cooled. This represented an improvement over previously tested engineering control devices by reducing their 
fire hazard potential (Earnest, Dunn et al. 2003). Additional testing is planned to determine the $\mathrm{CO}$ emissions after a full season of rental use to determine the performance of the catalytic control device.

\section{Westerbeke Generator Retrofitted with a Zenith EFI}

CO results for the older $12.5 \mathrm{KW}$ Westerbeke generator that had been retrofitted with an aftermarket EFI were quite good (Table IV-V). The cold start condition resulted in a transient increase in stack emissions that were greater than 11 percent CO. After approximately 5 minutes, the concentrations markedly dropped to a steady state value below 1,000 ppm. Considering that a catalytic air pollution control device was not added to this generator set, the steady state values are impressive. The generator had 202 hours of operation since the retrofit. Additional testing is planned to determine the $\mathrm{CO}$ emissions after a full year of rental use to determine the performance of the retrofitted generator after a full rental season of use.

\section{RECOMMENDATIONS}

The following recommendations are provided to reduce CO concentrations near houseboats and provide a safer and healthier environment.

1) All manufacturers/owners/users of U.S. houseboats with gasoline-powered generators should be aware of and concerned about the location of the exhaust terminus. Based on data from numerous NIOSH field surveys, we recommend that houseboats with gasoline-powered generators be evaluated for potential CO exposures and poisonings and retrofitted with control systems to reduce the potential hazard of CO poisoning.

2) The vertical exhaust stack on Fun Country Marine houseboats performed well during the current study. Based upon the results of this and previous NIOSH evaluations of the vertical exhaust stack, NIOSH research indicates that when properly designed and installed, the vertical stack is a viable, low-cost, engineering control that will dramatically improve the safety of houseboat users.

3) The performance of the Westerbeke Safe-CO ${ }^{\mathrm{TM}}$ generators was impressive with exhaust stack CO emissions of approximately $200 \mathrm{ppm}$ for a fully warmed generator. Due to diffusion, these emissions were significantly reduced such that highest average real-time CO reading, obtained from the monitors placed throughout the houseboat, was 9.3 ppm (side exhaust configuration). Given the low hours of operation for the two generators tested, it is important to conduct addition tests at the end of the houseboat season to determine if there is any performance degradation.

4) The performance of the Westerbeke generator retrofitted with a Zenith EFI was excellent with a stack CO emission below 1,000 ppm for the a fully warmed generator. Due to diffusion, these emissions were significantly reduced such that highest average real-time CO reading, obtained from the monitors placed throughout the houseboat, was 13 ppm (side exhaust configuration). Given the low hours of operation for this generator, it is important to conduct addition testing at the end of the houseboat season to determine if there is any degradation in performance. 
5) Public education efforts should continue to be utilized to immediately inform and warn all individuals (including boat owners, renters, and workers) potentially exposed to CO hazards. The U.S.N.P.S. (United States National Park Service) has launched an awareness campaign to inform boaters on their lakes about boat-related CO hazards. This Alert included press releases, flyers distributed to boat and dock-space renters, and verbal information included in the boat checkout training provided for users of concessionaire rental boats. Training about the specific boat-related CO hazards provided for houseboat renters, who may be completely unaware of this deadly hazard, should be enhanced to include specific information about the circumstances and number of poisonings and deaths. The training should specifically target warnings against entering air spaces under the boat (such as the cavity below the swim platform), or immediately near the swim platform or exhaust terminus that may contain a lethal atmosphere. Labeling should also be used for all exhaust terminus locations. 


\section{REFERENCES}

ABYC (2002) Standard P-1 Installation of Exhaust Systems for Propulsion and Auxilliary Engines. Edgewater, MD, American Boat and Yacht Council.

ACGIH (1996). Documentation of Threshold Limit Values and Biological Exposure Indices. Cincinnati, OH, American Conference of Governmental Industrial Hygienists.

CARB (1998). Evaluation of Unlimited Technologies International, Inc.'s Series SA090 New Aftermarket Three-way Catalytic Converter for Exemption From the Prohibitions in Vehicle Code Section 27156, and Title 13 California Code of Regulations Section 2222(h). El Monte, CA, State of California Air Resources Board: 6.

CDC (1988). MMWR 37, supp (S-7) NIOSH Recommendations for Occupational Safety and Health Standards. Atlanta, GA, Department of Health and Human Services, Public Health Service, Centers for Disease Control and Prevention, National Institute for Occupational Safety and Health.

CFR (1997). 29 CFR 1910.1000, Chapter XVII - Occupational Safety and Health Administration. Code of Federal Regulations, Table Z-1, Limits for Air Contaminants. Washington, DC: U.S. Federal Register.

CFR (1997). 29 CFR 1910.1000, Code of Federal Regulations. Washington, DC: U.S., Government Printing Office, Federal Register.

Dunn, K.H.; Earnest, G.S.; McCleery, R.; Hall, R.M.; McCammon, J.B.; Jones. A.L. [2001]: Comparison of a Dry Stack with Existing Generator Exhaust Systems for Prevention of Carbon Monoxide Poisonings on Houseboats. Cincinnati, OH: U.S. Department of Health and Human Services, Public Health Service, Centers for Disease Control and Prevention, National Institute for Occupational Safety and Health, DHHS (NIOSH) Publication No. ECTB 171-28a.

Dunn, K.H.; Hall, R.M.; McCammon, J.B.; Earnest, G.S. [2001]: An Evaluation of an Engineering Control to Prevent Carbon Monoxide Poisonings of Individuals On Houseboats at Sumerset Custom Houseboats, Somerset, KY. Cincinnati, OH: U.S. Department of Health and Human Services, Public Health Service, Centers for Disease Control and Prevention, National Institute for Occupational Safety and Health, DHHS (NIOSH) Publication No. ECTB 171-26a.

Earnest, G. S., R. L. Mickelsen, et al. (1997). "Carbon Monoxide Poisonings from Small, Gasoline-Powered, Internal Combustion Engines: Just What Is a "Well-Ventilated Area"?" Am. Ind. Hyg. Assoc. J. 58(11): 787-791. 
Earnest, G.S.; Dunn, K.H. Hall, R.M.; McCleery, R.; McCammon, J.B. [2001]: An Evaluation of an Engineering Control to Prevent Carbon Monoxide Poisonings of Individuals On and Around Houseboats. Cincinnati, OH: U.S. Department of Health and Human Services, Public Health Service, Centers for Disease Control and Prevention, National Institute for Occupational Safety and Health, DHHS (NIOSH) Publication No. ECTB 171-25a.

Earnest, G.S.; Dunn, K.H.; Hall, R.M.; McCleery, R.; McCammon, J.B. [2001]: An Evaluation of an Emission Control Device, Exhaust Stack, and Interlock to Prevent Carbon Monoxide Poisonings of Individuals On Houseboats. Cincinnati, OH: U.S. Department of Health and Human Services, Public Health Service, Centers for Disease Control and Prevention, National Institute for Occupational Safety and Health, DHHS (NIOSH) Publication No. ECTB 17127a.

Earnest, G. S., K. H. Dunn, et al. (2001). An Evaluation of an Emission Control Device, Exhaust Stack, and Interlock to Prevent Carbon Monoxide Poisonings of Individuals on Houseboats. Cincinnati, Oh, U.S. Dept. of Health and Human Services, Public Health Service, Centers for Disease Control and Prevention, National Institute for Occupational Safety and Health: 49.

Earnest G.S., Beamer, B., Dunn, K., [2002]. An Evaluation of an Side Exhaust and Prototype and Production Emission Control Devices to Prevent Carbon Monoxide Poisonings from Generator Exhaust on Houseboats. Lake Mead, Nevada. USDHHS, PHS, CDC, NIOSH, Cincinnati, Ohio, EPHB No. 171-29a.

Earnest, G.S., Hall, R.M., Dunn, K.H., Hammond, D., Valladares, R.,, [2003]. An Evaluation of Vertical Exhaust Stacks and Aged Production Emission Control Devices to Prevent Carbon Monoxide Poisonings from Houseboat Generator Exhaust. Lake Mead, Nevada. USDHHS, PHS, CDC, NIOSH, Cincinnati, Ohio, EPHB No. 171-32a.

Eastwood, P. (2000). Critical Topics in Exhaust Gas Aftertreatment. Hertfordshire, England, Research Studies Press Ltd.

Ehlers, J. J., J. B. McCammon, et al. (1996). NIOSH/CDPHE/CPSC/OSHA/EPA Alert: Preventing Carbon Monoxide Poisoning from Small Gasoline-Powered Engines and Tools, U.S. Department of Health and Human Services, Public Health Service, Centers for Disease Control and Prevention, National Institute for Occupational Safety and Health.

Envirolift (2001). Envirolift Product Literature. Charlotte, NC.

EPA (1991). Air Quality Criteria for Carbon Monoxide. Washington, DC, U.S. Environmental Protection Agency.

Forbes, W. H., F. Sargent, et al. (1945). “The Rate of CO Uptake by Normal Man.” Am Journal of Physiology 143:594-608. 
Hall, R. M. (2000). Letter of December 18, 2000 from Ronald M. Hall, National Institute for Occupational Safety and Health, Centers for Disease Control and Prevention, Public Health Service, U.S. Department of Health and Human Services and to Rice C. Leach, Commissioner, Cabinet for Health Services, Department of Public Health, Commonwealth of Kentucky. Cincinnati, OH, NIOSH: December 18, 2000.

Hall, R. M. and J. B. McCammon (2000). Letter of November 21, 2000 from Ronald M. Hall and Jane B. McCammon, National Institute for Occupational Safety and Health, Centers for Disease Control and Prevention, Public Health Service, U.S. Department of Health and Human Services and to Joe Alston, Park Superintendent, Glen Canyon National Recreation Area, Page, Arizona. Cincinnati, OH, NIOSH: November 21, 2000.

Heck, R.M. and Farrauto, R.J. (1995). Catalytic Air Pollution Control: Commercial Technology. New York, New York, John Wiley \& Sons, Inc.

Heywood, J. B. (1988). Internal Combustion Engine Fundamentals. New York, New York, McGraw-Hill Inc.

Imanna Laboratory, Inc. (2001) Certification Test Report 15530-1 of Ignition Protection Tests on Environmental Carbon Monoxide Reduction System, ENV-JHW-1001, Rockledge, Florida.

Kales, S. N. (1993). “Carbon Monoxide Intoxication.” American Family Physician 48(6):11001104.

Kovein, R. J., G. S. Earnest, et al. (1998). CO Poisoning from Small Gasoline-Powered Engines: A Control Technology Solution, U.S. Department of Health and Human Services, Public Health Service, Centers for Disease Control and Prevention, National Institute for Occupational Safety and Health.

MariTech (2001). Conversation between Dr. G. Scott Earnest of EPHB, DART, NIOSH, and Keith Jackson, President of MariTech Industries, July 24, 2001. Anderson, California.

McCammon, J. B. and T. Radtke (2000). Letter of September 28, 2000 from J. McCammon, National Institute for Occupational Safety and Health, Centers for Disease Control and Prevention, Public Health Service, U.S. Department of Health and Human Services and T. Radtke, U.S. Department of the Interior, to Joe Alston, Park Superintendent, Glen Canyon National Recreation Area, Page, Arizona. Denver, CO, NIOSH.

McCammon, J. B., T. Radtke, et al. (2001). Letter of February 20, 2001, from J. McCammon, National Institute for Occupational Safety and Health, Centers for Disease Control and Prevention, Public Health Service, U.S. Department of Health and Human Services, T. Radtke, U.S. Department of the Interior, and Dr. Robert Baron Prehospital Medical Care, 
Glen Canyon National Recreation Area, to Joe Alston, Park Superintendent, Glen Canyon National Recreation Area, Page, Arizona. Denver, CO, NIOSH.

NIOSH (1972). Criteria for a Recommended Standard: Occupational Exposure to Carbon Monoxide. Cincinnati, OH, National Institute for Occupational Safety and Health.

NIOSH (1977). Occupational Diseases: A Guide to their Recognition. Cincinnati, OH, National Institute for Occupational Safety and Health.

NIOSH (1979). A Guide to Work Relatedness of Disease. Cincinnati, OH, Department of Health Education and Welfare, Public Health Service, Centers for Disease Control, National Institute for Occupational Safety and Health.

NIOSH (2000). Pocket Guide to Chemical Hazards and Other Databases: Immediately Dangerous to Life and Health Concentrations, DHHS (NIOSH).

Plog, B. A. (1988). Fundamentals of Industrial Hygiene. Chicago, Illinois, National Safety Council.

Proctor, N. H., J. P. Hughes, et al. (1988). Chemical Hazards of the Workplace. Philadelphia, PA, J.P. Lippincott Co.

Simeone, L. F. (1990). A Simple Carburetor Model for Predicting Engine Air-Fuel Ratios and Carbon Monoxide Emissions as a Function of Inlet Conditions. Cambridge, Massachusetts, U.S. Department of Transportation, Research and Special Programs Administration: 11.

Westerbeke (2001). Conversation between Dr. G. Scott Earnest of EPHB, DART, NIOSH, and Carlton Bryant, Vice-President of Westerbeke Corporation, February 21, 2001. Avon, Massachusetts.

Westerbeke (2001). Unpublished Data: Engine exhaust emission test results. Taunton, MA: 2. 
Table I--CO Concentrations (ppm) on Fun Country Marine VIP XT (16' X59') Houseboat With a 14 KW Low-CO Westerbeke Generator in the Side-Exhaust Configuration (Generator - On,Test Date - 3/8/2005)

\begin{tabular}{|c|c|c|}
\hline $\begin{array}{l}\text { Sample Location } \\
\text { (Sample \#) }\end{array}$ & $\begin{array}{c}\text { Houseboat } \\
\text { Generator - No load }\end{array}$ & $\begin{array}{c}\text { Houseboat } \\
\text { Generator - 1/2 load }\end{array}$ \\
\hline $\begin{array}{l}\text { Lower Stern Deck } \\
\text { Starboard Side } \\
\text { (Sample \#1) }\end{array}$ & $\begin{array}{c}\text { Mean }=4.8 \\
\text { Std. Dev. }=13.2 \\
\text { Peak = 90 } \\
N=64\end{array}$ & $\begin{array}{c}\text { Mean }=1.9 \\
\text { Std. Dev. }=0.4 \\
\text { Peak }=3.0 \\
\mathrm{~N}=53\end{array}$ \\
\hline $\begin{array}{l}\text { Lower Stern Deck } \\
\text { Port Side } \\
\text { (Sample \#2) }\end{array}$ & $\begin{array}{c}\text { Mean }=9.3 \\
\text { Std. Dev. = } 11.6 \\
\text { Peak }=67 \\
N=64\end{array}$ & $\begin{array}{c}\text { Mean }=4.5 \\
\text { Std. Dev. }=2.5 \\
\text { Peak }=13.0 \\
\mathrm{~N}=53\end{array}$ \\
\hline $\begin{array}{l}\text { Lower Stern Deck } \\
\text { Starboard Side } \\
\text { (Sample \#3) }\end{array}$ & $\begin{array}{c}\text { Mean }=3.1 \\
\text { Std. Dev. }=0.4 \\
\text { Peak }=4.0 \\
N=64\end{array}$ & $\begin{array}{c}\text { Mean }=3.0 \\
\text { Std. Dev. }=0.9 \\
\text { Peak }=6.0 \\
N=53\end{array}$ \\
\hline $\begin{array}{l}\text { Lower Stern Deck } \\
\text { Port Side (on stair rail) } \\
\text { (Sample \#4) }\end{array}$ & $\begin{array}{c}\text { Mean }=1.3 \\
\text { Std. Dev. }=1.0 \\
\text { Peak }=3.0 \\
N=64\end{array}$ & $\begin{array}{c}\text { Mean }=1.0 \\
\text { Std. Dev. }=0.9 \\
\text { Peak }=2.0 \\
\mathrm{~N}=53\end{array}$ \\
\hline $\begin{array}{l}\text { Mid Deck } \\
\text { Cabin Kitchen } \\
\text { (Sample \#5) }\end{array}$ & $\begin{array}{c}\text { Mean }=1.3 \\
\text { Std. Dev. }=0.5 \\
\text { Peak }=2.0 \\
\mathrm{~N}=64\end{array}$ & $\begin{array}{c}\text { Mean }=1.2 \\
\text { Std. Dev. }=0.5 \\
\text { Peak }=2.0 \\
\mathrm{~N}=53\end{array}$ \\
\hline $\begin{array}{l}\text { Upper Stern Deck } \\
\text { Port Side } \\
\text { (Sample \#6) }\end{array}$ & $\begin{array}{c}\text { Mean }=2.0 \\
\text { Std. Dev. }=1.7 \\
\text { Peak }=10.0 \\
N=64\end{array}$ & $\begin{array}{c}\text { Mean }=1.3 \\
\text { Std. Dev. }=0.7 \\
\text { Peak }=3.0 \\
N=53\end{array}$ \\
\hline $\begin{array}{l}\text { Upper Stern Deck } \\
\text { Starboard Side } \\
\text { (Sample \#7) }\end{array}$ & $\begin{array}{c}\text { Mean }=6.4 \\
\text { Std. Dev. }=1.0 \\
\text { Peak }=9.0 \\
\mathrm{~N}=64\end{array}$ & $\begin{array}{c}\text { Mean }=5.4 \\
\text { Std. Dev. }=0.9 \\
\text { Peak }=8.0 \\
N=53\end{array}$ \\
\hline $\begin{array}{l}\text { Upper Stern Deck } \\
\text { Starboard Side } \\
\text { (Sample \#8) }\end{array}$ & $\begin{array}{c}\text { Mean }=1.8 \\
\text { Std. Dev. }=0.4 \\
\text { Peak }=3.0 \\
\mathrm{~N}=64\end{array}$ & $\begin{array}{c}\text { Mean }=1.7 \\
\text { Std. Dev. }=0.6 \\
\text { Peak }=3.0 \\
N=53\end{array}$ \\
\hline $\begin{array}{l}\text { Mid Deck } \\
\text { Wet Bar } \\
\text { (Sample \#9) }\end{array}$ & $\begin{array}{c}\text { Mean }=2.3 \\
\text { Std. Dev. }=0.5 \\
\text { Peak }=3.0 \\
N=64\end{array}$ & $\begin{array}{c}\text { Mean }=2.1 \\
\text { Std. Dev. }=0.5 \\
\text { Peak }=4.0 \\
\mathrm{~N}=53\end{array}$ \\
\hline
\end{tabular}

$\mathrm{N}=$ number of data points 
Table II--CO Concentrations (ppm) on Fun Country Marine VIP XT (16' X 59') Houseboat with a $14 \mathrm{KW}$ Low-CO Westerbeke Generator in the Top-Exhaust Configuration (Generator - On, Test Date - 3/8/2005)

\begin{tabular}{|c|c|c|}
\hline $\begin{array}{l}\text { Sample Location } \\
\text { (Sample \#) }\end{array}$ & $\begin{array}{c}\text { Houseboat } \\
\text { Generator - No load }\end{array}$ & $\begin{array}{c}\text { Houseboat } \\
\text { Generator - 1/2 load }\end{array}$ \\
\hline $\begin{array}{l}\text { Lower Stern Deck } \\
\text { Starboard Side } \\
\text { (Sample \#1) }\end{array}$ & $\begin{array}{c}\text { Mean }=2.1 \\
\text { Std. Dev. }=0.6 \\
\text { Peak }=5.0 \\
N=81\end{array}$ & $\begin{array}{c}\text { Mean }=2.8 \\
\text { Std. Dev. }=1.4 \\
\text { Peak }=8.0 \\
\mathrm{~N}=53\end{array}$ \\
\hline $\begin{array}{l}\text { Lower Stern Deck } \\
\text { Port Side } \\
\text { (Sample \#2) }\end{array}$ & $\begin{array}{c}\text { Mean }=6.9 \\
\text { Std. Dev. }=4.8 \\
\text { Peak }=15.0 \\
\mathrm{~N}=81\end{array}$ & $\begin{array}{c}\text { Mean }=6.3 \\
\text { Std. Dev. }=2.6 \\
\text { Peak }=11.0 \\
N=53\end{array}$ \\
\hline $\begin{array}{l}\text { Lower Stern Deck } \\
\text { Starboard Side } \\
\text { (Sample \#3) }\end{array}$ & $\begin{array}{c}\text { Mean }=3.8 \\
\text { Std. Dev. }=1.2 \\
\text { Peak }=7.0 \\
\mathrm{~N}==81\end{array}$ & $\begin{array}{c}\text { Mean }=3.4 \\
\text { Std. Dev. }=0.7 \\
\text { Peak }=5.0 \\
\quad \mathrm{~N}=53\end{array}$ \\
\hline $\begin{array}{l}\text { Lower Stern Deck } \\
\text { Port Side (on stair rail) } \\
\text { (Sample \#4) }\end{array}$ & $\begin{array}{c}\text { Mean }=2.0 \\
\text { Std. Dev. }=1.6 \\
\text { Peak }=6.0 \\
N=81\end{array}$ & $\begin{array}{c}\text { Mean }=1.5 \\
\text { Std. Dev. }=0.7 \\
\text { Peak }=4.0 \\
N=53\end{array}$ \\
\hline $\begin{array}{l}\text { Mid Deck } \\
\text { Cabin Kitchen } \\
\text { (Sample \#5) }\end{array}$ & $\begin{array}{c}\text { Mean }=1.4 \\
\text { Std. Dev. }=0.5 \\
\text { Peak }=2.0 \\
\mathrm{~N}=81\end{array}$ & $\begin{array}{c}\text { Mean }=1.3 \\
\text { Std. Dev. }=0.5 \\
\text { Peak }=2.0 \\
N=53\end{array}$ \\
\hline $\begin{array}{l}\text { Upper Stern Deck } \\
\text { Port Side } \\
\text { (Sample \#6) }\end{array}$ & $\begin{array}{c}\text { Mean }=2.2 \\
\text { Std. Dev. }=1.1 \\
\text { Peak }=5.0 \\
\mathrm{~N}=81\end{array}$ & $\begin{array}{c}\text { Mean }=1.9 \\
\text { Std. Dev. }=1.5 \\
\text { Peak }=8.0 \\
\mathrm{~N}=53\end{array}$ \\
\hline $\begin{array}{l}\text { Upper Stern Deck } \\
\text { Starboard Side } \\
\text { (Sample \#7) }\end{array}$ & $\begin{array}{c}\text { Mean }=7.6 \\
\text { Std. Dev. }=1.1 \\
\text { Peak }=11.0 \\
\mathrm{~N}=81\end{array}$ & $\begin{array}{c}\text { Mean }=7.8 \\
\text { Std. Dev. }=1.8 \\
\text { Peak }=14.0 \\
\mathrm{~N}=53\end{array}$ \\
\hline $\begin{array}{l}\text { Upper Stern Deck } \\
\text { Starboard Side } \\
\text { (Sample \#8) }\end{array}$ & $\begin{array}{c}\text { Mean }=2.0 \\
\text { Std. Dev. }=0.7 \\
\text { Peak }=4.0 \\
\mathrm{~N}=81\end{array}$ & $\begin{array}{c}\text { Mean }=2.0 \\
\text { Std. Dev. }=0.8 \\
\text { Peak }=6.0 \\
\quad \mathrm{~N}=53\end{array}$ \\
\hline $\begin{array}{l}\text { Mid Deck } \\
\text { Wet Bar } \\
\text { (Sample \#9) }\end{array}$ & $\begin{array}{c}\text { Mean }=2.2 \\
\text { Std. Dev. }=0.5 \\
\text { Peak }=3.0 \\
\mathrm{~N}=81\end{array}$ & $\begin{array}{c}\text { Mean }=2.2 \\
\text { Std. Dev. }=0.6 \\
\text { Peak }=5.0 \\
N=53\end{array}$ \\
\hline
\end{tabular}

$\mathrm{N}=$ number of data points 
Table III--CO Concentrations (ppm) on Fun Country Marine VIP XT (16' X 70') Houseboat with a $20 \mathrm{KW}$ Low-CO Westerbeke Generator Equipped with a Top-Exhaust (Generator - On,Test Date - 3/9/2005)

\begin{tabular}{|c|c|c|}
\hline $\begin{array}{l}\text { Sample Location } \\
\text { (Sample \#) }\end{array}$ & $\begin{array}{c}\text { Houseboat } \\
\text { Generator - No load }\end{array}$ & $\begin{array}{c}\text { Houseboat } \\
\text { Generator }-1 / 2 \text { load }\end{array}$ \\
\hline $\begin{array}{l}\text { Lower Stern Deck } \\
\text { Starboard Side } \\
\text { (Sample \#1) }\end{array}$ & $\begin{array}{c}\text { Mean }=2.1 \\
\text { Std. Dev. = 2.0 } \\
\text { Peak }=7.0 \\
N=83\end{array}$ & $\begin{array}{c}\text { Mean }=0.5 \\
\text { Std. Dev. }=0.5 \\
\text { Peak }=1.0 \\
\mathrm{~N}=31\end{array}$ \\
\hline $\begin{array}{l}\text { Lower Stern Deck } \\
\text { Port Side } \\
\text { (Sample \#2) }\end{array}$ & $\begin{array}{c}\text { Mean }=0.7 \\
\text { Std. Dev. }=1.0 \\
\text { Peak }=4.0 \\
N=83\end{array}$ & $\begin{array}{c}\text { Mean }=0.2 \\
\text { Std. Dev. }=0.4 \\
\text { Peak }=1.0 \\
\mathrm{~N}=31\end{array}$ \\
\hline $\begin{array}{l}\text { Lower Stern Deck } \\
\text { Starboard Side } \\
\text { (Sample \#3) }\end{array}$ & $\begin{array}{c}\text { Mean }=0.9 \\
\text { Std. Dev. }=1.0 \\
\text { Peak }=4.0 \\
\mathrm{~N}=83\end{array}$ & $\begin{array}{c}\text { Mean }=0.3 \\
\text { Std. Dev. }=0.5 \\
\text { Peak }=1.0 \\
\mathrm{~N}=31\end{array}$ \\
\hline $\begin{array}{l}\text { Lower Stern Deck } \\
\text { Port Side (on stair rail) } \\
\text { (Sample \#4) }\end{array}$ & $\begin{array}{c}\text { Mean }=1.0 \\
\text { Std. Dev. }=1.2 \\
\text { Peak }=6.0 \\
\mathrm{~N}=83\end{array}$ & $\begin{array}{c}\text { Mean }=0.5 \\
\text { Std. Dev. }=0.5 \\
\text { Peak }=1.0 \\
\mathrm{~N}=31\end{array}$ \\
\hline $\begin{array}{l}\text { Mid Deck } \\
\text { Cabin Kitchen } \\
\text { (Sample \#5) }\end{array}$ & $\begin{array}{c}\text { Mean }=1.6 \\
\text { Std. Dev. }=1.1 \\
\text { Peak }=5.0 \\
\mathrm{~N}=83\end{array}$ & $\begin{array}{c}\text { Mean }=1.0 \\
\text { Std. Dev. }=0.3 \\
\text { Peak }=2.0 \\
N=31\end{array}$ \\
\hline $\begin{array}{l}\text { Upper Stern Deck } \\
\text { Port Side } \\
\text { (Sample \#6) }\end{array}$ & $\begin{array}{c}\text { Mean }=1.9 \\
\text { Std. Dev. }=1.2 \\
\text { Peak }=6.0 \\
\mathrm{~N}=83\end{array}$ & $\begin{array}{c}\text { Mean }=1.3 \\
\text { Std. Dev. }=0.5 \\
\text { Peak }=1.0 \\
\mathrm{~N}=31\end{array}$ \\
\hline $\begin{array}{l}\text { Upper Stern Deck } \\
\text { Starboard Side } \\
\text { (Sample \#7) }\end{array}$ & $\begin{array}{c}\text { Mean }=3.7 \\
\text { Std. Dev. }=2.2 \\
\text { Peak }=10.0 \\
N=83\end{array}$ & $\begin{array}{c}\text { Mean }=1.9 \\
\text { Std. Dev. }=0.3 \\
\text { Peak }=1.0 \\
\mathrm{~N}=31\end{array}$ \\
\hline $\begin{array}{l}\text { Upper Stern Deck } \\
\text { Starboard Side } \\
\text { (Sample \#8) }\end{array}$ & $\begin{array}{c}\text { Mean }=0.9 \\
\text { Std. Dev. }=1.4 \\
\text { Peak }=7.0 \\
\mathrm{~N}=83\end{array}$ & $\begin{array}{c}\text { Mean }=0.1 \\
\text { Std. Dev. }=0.3 \\
\text { Peak }=1.0 \\
\mathrm{~N}=31\end{array}$ \\
\hline $\begin{array}{l}\text { Mid Deck } \\
\text { Wet Bar } \\
\text { (Sample \#9) }\end{array}$ & $\begin{array}{c}\text { Mean }=1.5 \\
\text { Std. Dev. }=1.1 \\
\text { Peak }=6.0 \\
\mathrm{~N}=83\end{array}$ & $\begin{array}{c}\text { Mean }=1.0 \\
\text { Std. Dev. = } 0.3 \\
\text { Peak }=2.0 \\
N=31\end{array}$ \\
\hline
\end{tabular}

$\mathrm{N}=$ number of data points 
Table IV--CO Concentrations (ppm) on Fun Country Marine (14' X 59') Houseboat with a 12.5 KW Westerbeke Generator Retrofitted with a Zenith Electronic Fuel Injection Kit and a Top-Exhaust (Generator - On,Test Date - 3/9/2005)

\begin{tabular}{|c|c|c|}
\hline $\begin{array}{l}\text { Sample Location } \\
\text { (Sample \#) }\end{array}$ & $\begin{array}{c}\text { Houseboat } \\
\text { Generator - No load }\end{array}$ & $\begin{array}{c}\text { Houseboat } \\
\text { Generator }-1 / 2 \text { load }\end{array}$ \\
\hline $\begin{array}{l}\text { Lower Stern Deck } \\
\text { Starboard Side } \\
\text { (Sample \#1) }\end{array}$ & $\begin{array}{c}\text { Mean }=1.2 \\
\text { Std. Dev. }=0.9 \\
\text { Peak }=5.0 \\
N=28\end{array}$ & $\begin{array}{c}\text { Mean }=1.0 \\
\text { Std. Dev. }=0.4 \\
\text { Peak }=2.0 \\
N=21\end{array}$ \\
\hline $\begin{array}{l}\text { Lower Stern Deck } \\
\text { Port Side } \\
\text { (Sample \#2) }\end{array}$ & $\begin{array}{c}\text { Mean }=13.0 \\
\text { Std. Dev. }=1.4 \\
\text { Peak }=18.0 \\
N=28\end{array}$ & $\begin{array}{c}\text { Mean }=8.5 \\
\text { Std. Dev. }=2.7 \\
\text { Peak }=15.0 \\
\mathrm{~N}=21\end{array}$ \\
\hline $\begin{array}{l}\text { Lower Stern Deck } \\
\text { Starboard Side } \\
\text { (Sample \#3) }\end{array}$ & $\begin{array}{c}\text { Mean }=0.9 \\
\text { Std. Dev. }=0.6 \\
\text { Peak }=3.0 \\
\mathrm{~N}=28\end{array}$ & $\begin{array}{c}\text { Mean }=1.0 \\
\text { Std. Dev. }=0.4 \\
\text { Peak }=2.0 \\
\mathrm{~N}=21\end{array}$ \\
\hline $\begin{array}{l}\text { Lower Stern Deck } \\
\text { Port Side (on stair rail) } \\
\text { (Sample \#4) }\end{array}$ & $\begin{array}{c}\text { Mean }=0.2 \\
\text { Std. Dev. }=0.5 \\
\text { Peak }=2.0 \\
\mathrm{~N}=28\end{array}$ & $\begin{array}{c}\text { Mean }=1.0 \\
\text { Std. Dev. }=0.4 \\
\text { Peak }=2.0 \\
\mathrm{~N}=21\end{array}$ \\
\hline $\begin{array}{l}\text { Mid Deck } \\
\text { Cabin Kitchen } \\
\text { (Sample \#5) }\end{array}$ & $\begin{array}{c}\text { Mean }=0.5 \\
\text { Std. Dev. }=0.5 \\
\text { Peak }=1.0 \\
\mathrm{~N}=28\end{array}$ & $\begin{array}{c}\text { Mean }=0.3 \\
\text { Std. Dev. }=0.5 \\
\text { Peak }=1.0 \\
\mathrm{~N}=21\end{array}$ \\
\hline $\begin{array}{l}\text { Upper Stern Deck } \\
\text { Port Side } \\
\text { (Sample \#6) }\end{array}$ & $\begin{array}{c}\text { Mean }=2.8 \\
\text { Std. Dev. }=1.0 \\
\text { Peak }=6.0 \\
\mathrm{~N}=28\end{array}$ & $\begin{array}{c}\text { Mean }=2.7 \\
\text { Std. Dev. }=1.2 \\
\text { Peak }=6.0 \\
\mathrm{~N}=21\end{array}$ \\
\hline $\begin{array}{l}\text { Upper Stern Deck } \\
\text { Starboard Side } \\
\text { (Sample \#7) }\end{array}$ & $\begin{array}{c}\text { Mean }=7.9 \\
\text { Std. Dev. }=1.5 \\
\text { Peak }=5.0 \\
\mathrm{~N}=28\end{array}$ & $\begin{array}{c}\text { Mean }=7.0 \\
\text { Std. Dev. }=0.7 \\
\text { Peak }=8.0 \\
\mathrm{~N}=21\end{array}$ \\
\hline $\begin{array}{l}\text { Upper Stern Deck } \\
\text { Starboard Side } \\
\text { (Sample \#8) }\end{array}$ & $\begin{array}{c}\text { Mean }=3.0 \\
\text { Std. Dev. }=0.7 \\
\text { Peak }=5.0 \\
\mathrm{~N}=28\end{array}$ & $\begin{array}{c}\text { Mean }=2.9 \\
\text { Std. Dev. }=0.6 \\
\text { Peak }=4.0 \\
\mathrm{~N}=21\end{array}$ \\
\hline $\begin{array}{l}\text { Mid Deck } \\
\text { Wet Bar } \\
\text { (Sample \#9) }\end{array}$ & $\begin{array}{c}\text { Mean }=0.6 \\
\text { Std. Dev. }=0.6 \\
\text { Peak }=2.0 \\
N=28\end{array}$ & $\begin{array}{c}\text { Mean }=0.6 \\
\text { Std. Dev. = 0.4 } \\
\text { Peak }=2.0 \\
N=21\end{array}$ \\
\hline
\end{tabular}

$\mathrm{N}=$ number of data points 
Table V -- CO Grab Sample Results (ppm) Taken Adjacent (Side Exhaust Configuration, 24" above the exhaust) or within the Exhaust Plumes (Top Exhaust Configuration)

\begin{tabular}{|c|c|c|c|c|}
\hline $\begin{array}{l}\text { Boat, Condition } \\
\text { (Test Date) }\end{array}$ & $\begin{array}{l}\text { Sample } \\
\text { Type }\end{array}$ & Load & $\begin{array}{l}\text { Time }^{\mathrm{a}} \\
(\mathrm{min})\end{array}$ & $\begin{array}{l}\text { Sample } \\
\text { Result }\end{array}$ \\
\hline $\begin{array}{l}\text { Fun Country VIP XT } \\
\text { (16’ X 59') Houseboat } \\
\text { Equipped with a } 14 \mathrm{KW} \\
\text { Low CO Generator in } \\
\text { the Side Exhaust } \\
\text { Configuration }(3 / 8 / 2005)\end{array}$ & $\begin{array}{l}\text { Ferret Instrument } \\
\text { Draeger tube (2-60 ppm range) } \\
\text { Ferret Instrument } \\
\text { Draeger tube (10-3000 ppm range) } \\
\text { Evacuated chamber } \\
\text { Evacuated chamber }\end{array}$ & $\begin{array}{l}\text { none } \\
\text { none } \\
\text { none } \\
\text { none } \\
\text { none } \\
\text { none }\end{array}$ & $\begin{array}{l}0.25 \\
0.5 \\
0.5 \\
0.5 \\
1 \\
8\end{array}$ & $\begin{array}{l}\text { ND } \\
2 \\
\text { ND } \\
\text { ND } \\
126 \\
\text { ND }\end{array}$ \\
\hline $\begin{array}{l}\text { Fun Country VIP XT } \\
\text { (16’ X 59') Houseboat } \\
\text { Equipped with a } 14 \mathrm{KW} \\
\text { Low CO Generator in } \\
\text { the Side Exhaust } \\
\text { Configuration }(3 / 8 / 2005)\end{array}$ & $\begin{array}{l}\text { Ferret Instrument } \\
\text { Ferret Instrument } \\
\text { Draeger tube (2-60 ppm range) } \\
\text { Evacuated chamber } \\
\text { Draeger tube (2-60 ppm range) } \\
\text { Evacuated chamber } \\
\text { Evacuated chamber }\end{array}$ & $\begin{array}{l}1 / 2 \\
1 / 2 \\
1 / 2 \\
1 / 2 \\
1 / 2 \\
1 / 2 \\
1 / 2\end{array}$ & $\begin{array}{l}0.25 \\
0.5 \\
0.5 \\
0.5 \\
1 \\
1 \\
7\end{array}$ & $\begin{array}{l}\text { ND } \\
\text { ND } \\
\text { ND } \\
16 \\
\text { ND } \\
\text { ND } \\
\text { ND }\end{array}$ \\
\hline $\begin{array}{l}\text { Fun Country VIP XT } \\
\text { (16’ X 59') Houseboat } \\
\text { Equipped with a } 14 \mathrm{KW} \\
\text { Low CO Generator in } \\
\text { the Top Exhaust } \\
\text { Configuration }(3 / 8 / 2005)\end{array}$ & $\begin{array}{l}\text { Ferret Instrument } \\
\text { Draeger tube (10-3000 ppm range) } \\
\text { Ferret Instrument } \\
\text { Draeger tube (10-3000 ppm range) } \\
\text { Evacuated chamber } \\
\text { Draeger tube (2-60 ppm range) } \\
\text { Evacuated chamber } \\
\text { Evacuated chamber } \\
\text { Draeger tube (10-3000 ppm range) }\end{array}$ & $\begin{array}{l}\text { none } \\
\text { none } \\
\text { none } \\
\text { none } \\
\text { none } \\
\text { none } \\
\text { none } \\
\text { none } \\
\text { none }\end{array}$ & $\begin{array}{l}0.5 \\
0.5 \\
0.5 \\
0.5 \\
3 \\
4 \\
4 \\
5 \\
6\end{array}$ & $\begin{array}{l}15600^{\mathrm{b}} \\
>3000 \\
1500 \\
1100 \\
6 \\
\mathrm{ND} \\
155 \\
8 \\
\mathrm{ND}\end{array}$ \\
\hline $\begin{array}{l}\text { Fun Country VIP XT } \\
\text { (16’ X 59') Houseboat } \\
\text { Equipped with a } 14 \mathrm{KW} \\
\text { Low CO Generator in } \\
\text { the Top Exhaust } \\
\text { Configuration }(3 / 8 / 2005)\end{array}$ & $\begin{array}{l}\text { Ferret Instrument } \\
\text { Draeger tube (2-60 ppm range) } \\
\text { Draeger tube (2-60 ppm range) } \\
\text { Evacuated chamber } \\
\text { Evacuated chamber } \\
\text { Evacuated chamber }\end{array}$ & $\begin{array}{l}1 / 2 \\
1 / 2 \\
1 / 2 \\
1 / 2 \\
1 / 2 \\
1 / 2\end{array}$ & $\begin{array}{l}0.5 \\
0.5 \\
0.5 \\
2 \\
5 \\
6\end{array}$ & $\begin{array}{l}\text { ND } \\
30 \\
20 \\
\text { ND } \\
4 \\
\text { ND }\end{array}$ \\
\hline
\end{tabular}

$\mathrm{ND}=$ non detected; ${ }^{\mathrm{a}}$ Time after the start of the condition; ${ }^{\mathrm{b}}$ Average of five readings 
Table V (continued) -- CO Grab Sample Results (ppm) Taken Adjacent (Side Exhaust Configuration, 24" above the exhaust) or within the Exhaust Plumes (Top Exhaust Configuration).

\begin{tabular}{|c|c|c|c|c|}
\hline $\begin{array}{l}\text { Boat, Condition } \\
\text { (Test Date) }\end{array}$ & $\begin{array}{l}\text { Sample } \\
\text { Type }\end{array}$ & Load & $\begin{array}{l}\text { Time }^{a} \\
(\min )\end{array}$ & $\begin{array}{l}\text { Sample } \\
\text { Result }\end{array}$ \\
\hline $\begin{array}{l}\text { Fun Country VIP XT } \\
\text { (16’ X 70') Houseboat } \\
\text { Equipped with a } 20 \mathrm{KW} \\
\text { Low CO Generator in } \\
\text { the Top Exhaust } \\
\text { Configuration (3/9/2005) }\end{array}$ & $\begin{array}{l}\text { Ferret Instrument } \\
\text { Draeger tube (3000-70000 ppm ) } \\
\text { Ferret Instrument } \\
\text { Evacuated chamber } \\
\text { Draeger tube (10-3000 ppm range) } \\
\text { Evacuated chamber } \\
\text { Draeger tube (10-3000 ppm range) }\end{array}$ & $\begin{array}{l}\text { none } \\
\text { none } \\
\text { none } \\
\text { none } \\
\text { none } \\
\text { none } \\
\text { none }\end{array}$ & $\begin{array}{l}0.5 \\
0.5 \\
1 \\
1 \\
3 \\
6 \\
11\end{array}$ & $\begin{array}{l}48000^{\mathrm{b}} \\
58000 \\
103000^{\mathrm{b}} \\
116000 \\
200 \\
\text { ND } \\
100\end{array}$ \\
\hline $\begin{array}{l}\text { Fun Country VIP XT } \\
\text { (16’ X 70') Houseboat } \\
\text { Equipped with a } 20 \mathrm{KW} \\
\text { Low CO Generator in } \\
\text { the Top Exhaust } \\
\text { Configuration (3/9/2005) }\end{array}$ & $\begin{array}{l}\text { Ferret Instrument } \\
\text { Ferret Instrument } \\
\text { Draeger tube (10-3000 ppm range) } \\
\text { Evacuated chamber } \\
\text { Draeger tube (10-3000 ppm range) }\end{array}$ & $\begin{array}{l}1 / 2 \\
1 / 2 \\
1 / 2 \\
1 / 2 \\
1 / 2\end{array}$ & $\begin{array}{l}0.5 \\
1 \\
1 \\
2 \\
21\end{array}$ & $\begin{array}{l}1700^{\mathrm{b}} \\
200^{\mathrm{b}} \\
200 \\
230 \\
240\end{array}$ \\
\hline $\begin{array}{l}\text { Fun Country (14’ X 59’) } \\
\text { Houseboat Equipped } \\
\text { with a } 12.5 \mathrm{KW} \\
\text { Generator Configured } \\
\text { with a Zenith EFI and } \\
\text { Top Exhaust } \\
\text { Configuration (3/9/2005) }\end{array}$ & $\begin{array}{l}\text { Ferret Instrument } \\
\text { Draeger tube (3000-70000 ppm) } \\
\text { Evacuated chamber } \\
\text { Evacuated chamber } \\
\text { Draeger tube (3000-70000 ppm) } \\
\text { Evacuated chamber } \\
\text { Draeger tube (10-3000 ppm range) }\end{array}$ & $\begin{array}{l}\text { none } \\
\text { none } \\
\text { none } \\
\text { none } \\
\text { none } \\
\text { none } \\
\text { none }\end{array}$ & $\begin{array}{l}0.5 \\
0.5 \\
0.5 \\
2 \\
3 \\
4 \\
10\end{array}$ & $\begin{array}{l}30000^{\mathrm{b}} \\
60000 \\
117000 \\
37000 \\
20000 \\
466 \\
900\end{array}$ \\
\hline $\begin{array}{l}\text { Fun Country (14’ X 59’) } \\
\text { Houseboat Equipped } \\
\text { with a } 12.5 \mathrm{KW} \\
\text { Generator Configured } \\
\text { with a Zenith EFI and } \\
\text { Top Exhaust } \\
\text { Configuration (3/9/2005) }\end{array}$ & $\begin{array}{l}\text { Ferret Instrument } \\
\text { Draeger tube (3000-70000 ppm) } \\
\text { Draeger tube (10-3000 ppm range) } \\
\text { Evacuated chamber } \\
\text { Draeger tube (10-3000 ppm range) }\end{array}$ & $\begin{array}{l}1 / 2 \\
1 / 2 \\
1 / 2 \\
1 / 2 \\
1 / 2\end{array}$ & $\begin{array}{l}0.5 \\
2 \\
3 \\
9 \\
12\end{array}$ & $\begin{array}{l}19400 \\
3000 \\
700 \\
595 \\
600\end{array}$ \\
\hline
\end{tabular}

$\mathrm{ND}=$ non detected; ${ }^{\mathrm{a}}$ Time after the start of the condition; ${ }^{\mathrm{b}}$ average of five readings 
Table VI -- Boat Heading and Weather Data.

\begin{tabular}{lccccc}
\hline Day & $\begin{array}{c}\text { Houseboat } \\
\text { Bearing }\end{array}$ & $\begin{array}{c}\left.\text { Temp ( }{ }^{\circ} \mathbf{C}\right) / \\
\text { RH (\%) }\end{array}$ & $\begin{array}{c}\text { Average } \\
\text { Wind } \\
\text { direction }\end{array}$ & $\begin{array}{c}\text { Average } \\
\text { Wind } \\
\text { Speed }\end{array}$ & $\begin{array}{c}\text { Std. Dev. } \\
\text { Wind Speed }\end{array}$ \\
\hline $\begin{array}{l}\text { 3/8/2005, } \\
\text { morning }\end{array}$ & $300^{\circ}$ & $\begin{array}{c}17.2 / \\
59\end{array}$ & $119^{\circ}$ & $0.6 \mathrm{~m} / \mathrm{sec}$ & $0.4 \mathrm{~m} / \mathrm{sec}$ \\
\hline $\begin{array}{l}\text { 3/8/2005, } \\
\text { afternoon }\end{array}$ & $300^{\circ}$ & $\begin{array}{c}26.1 / \\
28\end{array}$ & $130^{\circ}$ & $1.4 \mathrm{~m} / \mathrm{sec}$ & $0.3 \mathrm{~m} / \mathrm{sec}$ \\
\hline $\begin{array}{l}\text { 3/9/2005, } \\
\text { morning }\end{array}$ & $300^{\circ}$ & $18.9 /$ & & $1.8 \mathrm{~m} / \mathrm{sec}$ & $0.7 \mathrm{~m} / \mathrm{sec}$ \\
\hline $\begin{array}{l}4 / 9 \\
\text { afternoon }\end{array}$ & $300^{\circ}$ & $25.6 /$ & $116^{\circ}$ & & \\
\hline
\end{tabular}


Figure 1. Westerbeke Low CO Generator (top) and Catalytic Air Pollution Control Device (bottom).
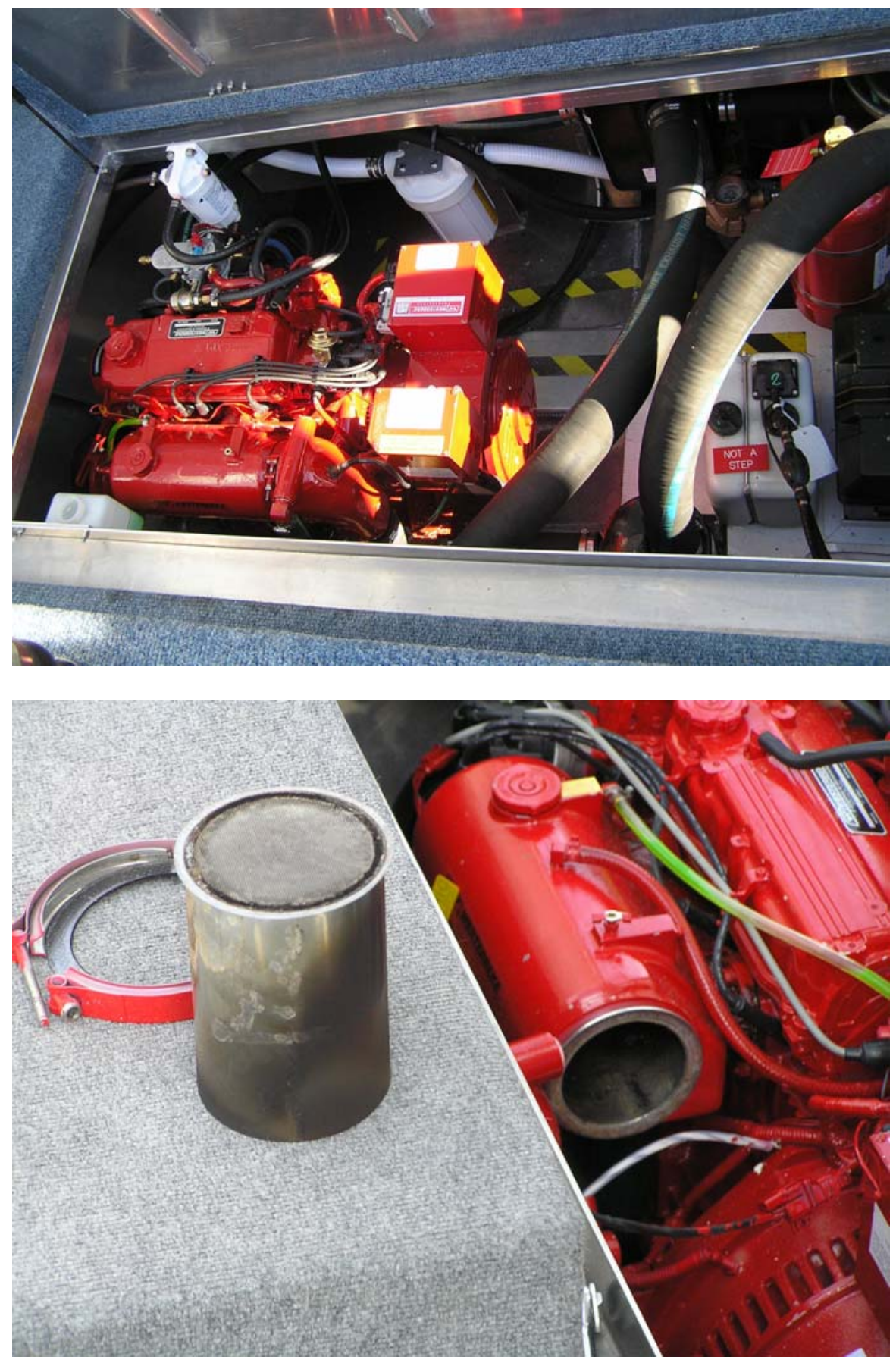
Figure 2. Sample locations on the Fun Country Marine Houseboats (Note: Fun Country VIP XT (16' X 59') schematics were used in this figure although all of the houseboats tested had similar layouts).
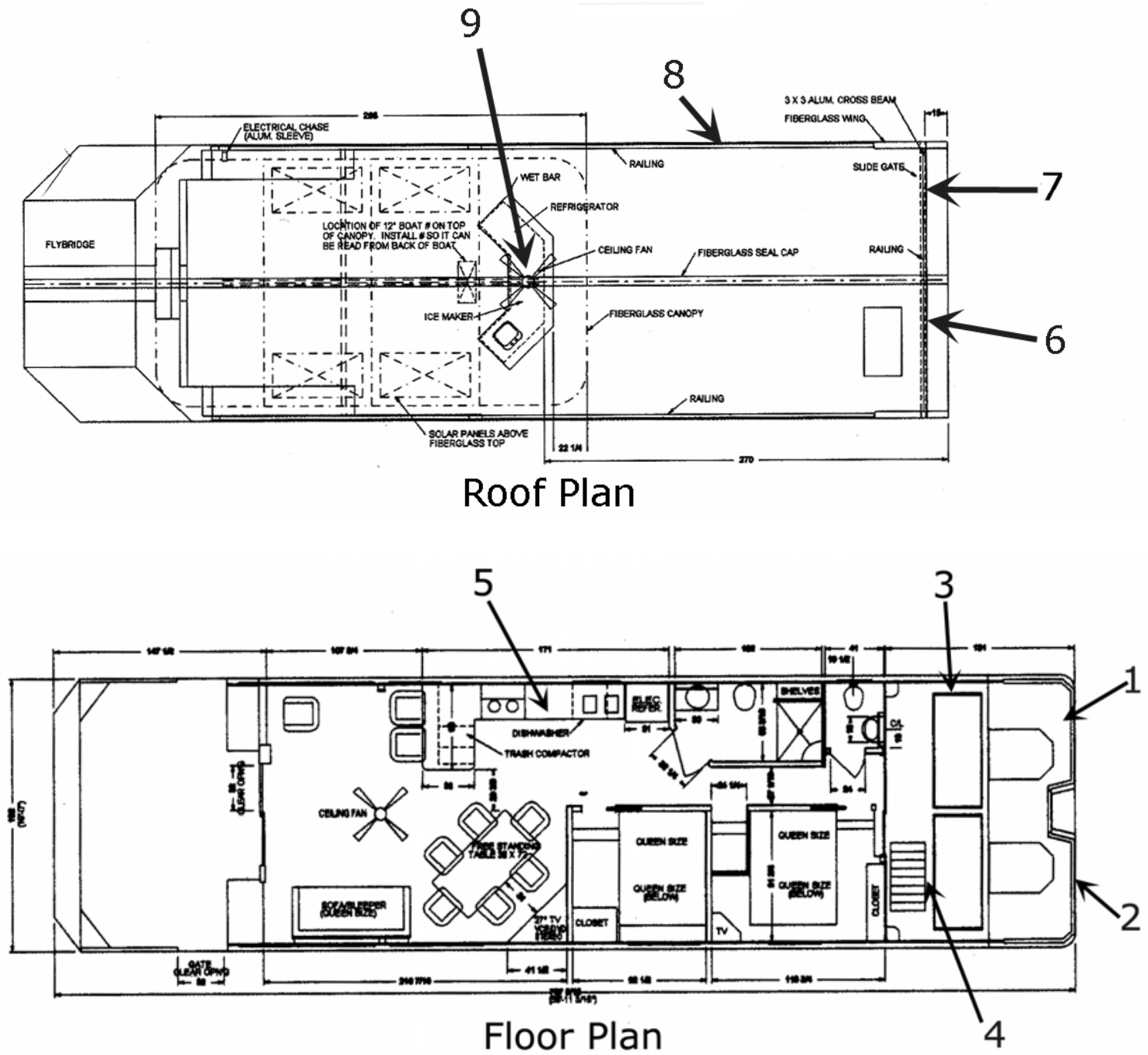